\title{
SOME ENGINEERING FACTORS AFFECTING THE PERFORMANCE OF SOLAR POWERED ADSORPTION REFRIGEARTION SYSTEM
}

\author{
Ghanem T. H.* Badr M. M.** Hafez H. *** Eissa A. S. ****
}

\begin{abstract}
In the present study three different collector cover materials, single or, double glazing and Polyethylene-plastic cover materials three different adsorbent material masses 12, 14 and $16 \mathrm{~kg}$ were used respectively for the determination of the optimal collector cover material and adsorbent mass proportion to methanol quantity. Collector thermal efficiency as affected by daily incident solar radiations $\mathrm{kW} . \mathrm{hr} / \mathrm{m} 2 /$ day and their effect on methanol saturation which directly reflected on the coefficient of performance for the refrigeration cycle were studied. Refrigeration load in ton of refrigeration and economical evaluation were also studied. Results showed that daily average solar radiation during these experiments was ranged between 6.6 to $7.9 \mathrm{~kW} . \mathrm{h} / \mathrm{m}^{2}$.day, the double glass cover material has the largest efficiency than both of single and polyethylene-plastic sheet, the thermal efficiency of single, double glazing and polyethylene plastic sheet cover were $30.27 \%, 39.83 \%$ and $30.22 \%$ respectively. It is clear that the double glazing cover is the optimal cover material of all studied cover materials. Higher values of C.O.P \% and refrigeration load were recorded for the $14 \mathrm{~kg}$ carbon mass than that of 12 and $16 \mathrm{~kg}$ carbon mas.
\end{abstract}

\section{INTRODUCTION}

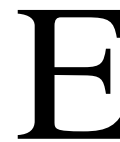

gypt is one of the countries having solar energy in abundance. The solar energy incident on the Egyptian land has a magnitude of 12$30 \mathrm{MJ} / \mathrm{m}^{2} /$ day, and the sunshine duration is between $3500-$ $4500 \mathrm{hr}$ per year. Solar energy can solve apart of energy demand problem however the use of solar energy in Egypt could play a useful role in satisfying energy requirements of most urban areas in appropriate circumstances. (El-Metwally 2005).

\footnotetext{
* Prof. of Ag. Products Processing Eng. Dept. Fac. of Agric. Eng. Al-Azhar Univ. ** Assi. Prof. of Ag. Products Processing Eng. Dept. Fac. of Agric. Eng. Al-Azhar Univ. *** Assi. Prof. Environmental Studies and Research Institute (, Sadat City, Egypt Univ. ***Assi. lecturer. of Ag. Products Processing Eng. Dept. Fac. of Agric. Eng. Al-Azhar Univ.
} 
The solar energy is used as a renewable source of energy for many applications. Solar refrigeration forms one of the most important applications of solar energy. Recently, solar energy has received interest as an alternative energy source for refrigeration systems, especially in places where electricity is expensive. Darwesh et al. (2010). The solar adsorption refrigeration technology has attracted some researchers since last decade because it is clean, cheap and simple for use in air conditioning, ice making, food preservation and vaccine storage. Qasem and El-Shaarawi (2013), Performed experiments with a solar powered ice maker that had activated carbon- methanol as working pair. In This icemaker, had a COP ranging from 0.12 to 0.14 , analyzing the temperature gradient within the adsorbent bed, the authors concluded that in order to improve the performance of this system, the heat transfer properties of the adsorber must be enhanced. This could be achieved by increasing the number of fins or using consolidated adsorbent. Li et al. (2002), the characteristics of solar cooler are affected by many parameters. Generally speaking, we can divide these parameters into two types. One type is the parametric parameters, such as dimensions, material and characteristics of collector, which decides the physical property ofcollector. Another type of parameters is environmental parameters, such as radiation intensity, ambient temperature and wind speed, which affect the running quality of system performance. Wang et al. (2000).

\section{The main objectives of the present study are:}

1. Constructing and manufacturing solar powered adsorption refrigeration system,

2. Study some engineering factors affecting the coefficient of performance and refrigeration load for the system.

\section{MATERIALS AND METHODS}

\section{MATERIALS}

The solar powered adsorption refrigeration system was designed and constructed in the collage of Agr. Eng. Al-Azhar Univ. Nasr City Cairo. The refrigeration system was fabricated and processed in the workshop of the Faculty of Agr. Eng. and other private workshops. The experimental part of this study was carried out in Dairut - Asyut ( - ديروط 
(اسيوط) at $27^{\circ} 32 \mathrm{~N}$ and $30^{\circ} 49 \mathrm{E}$ since the availability of sunshine higher and clear solar insolation.

\section{System Description}

The solar adsorption refrigeration system consists of four main components: a solar collector (generator) directly in contact with adsorbent material, a condenser, an evaporator and cooling chamber as shown in Fig. (3.1)

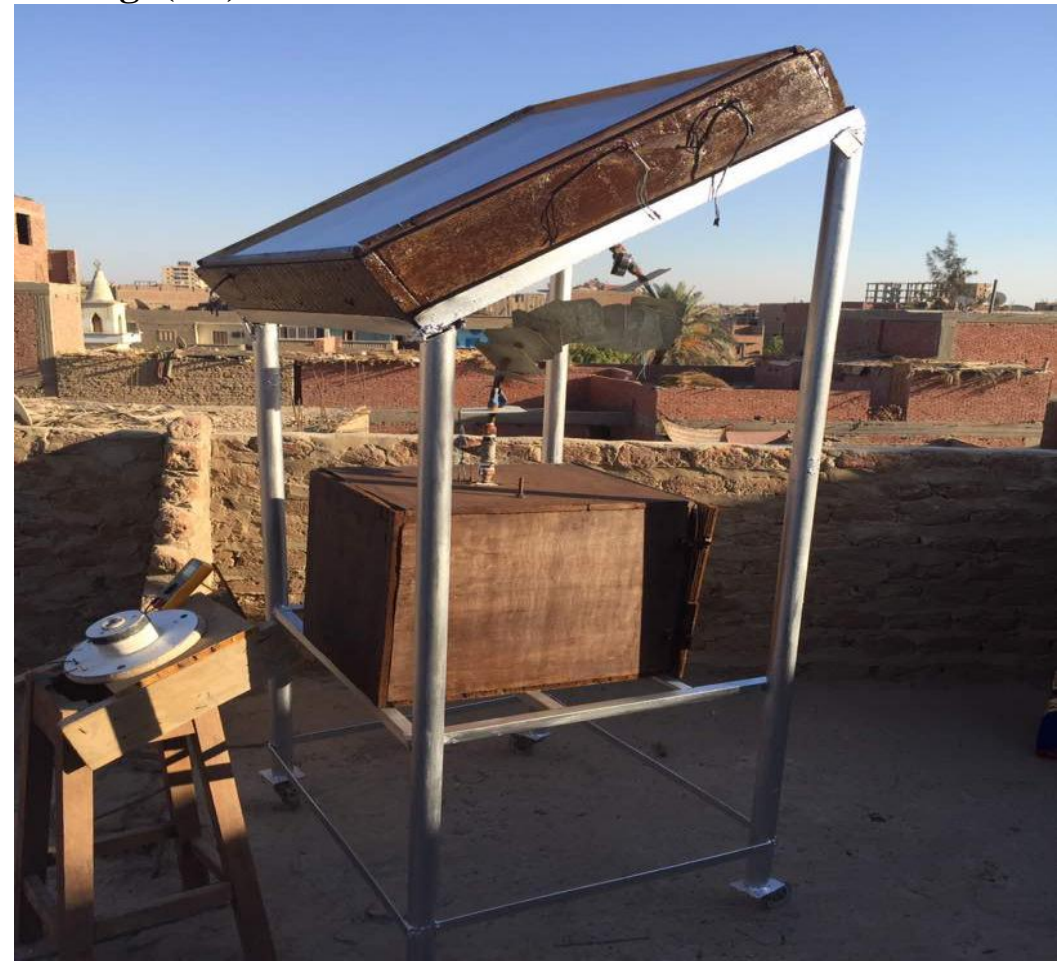

Fig.(3.1) Photograph of The solar powered adsorption refrigeration system setup.

\section{Solar Collector (Generator)}

The solar collector in consisted of three parallel layers, the first one is the adsorbent plate directly in contact with seven fins of stainless steel sheet longitudinally fixed underneath the collector absorber plate $0.1 \mathrm{~m}$ apart and $0.001 \mathrm{~m}$ thick to improve the heat and mass transfer process. The second is a parallel perforated steel sheet 0.001 thick. The activated carbon is packed between the first and second layer included fins. The third layer is installed $0.01 \mathrm{~m}$ part of the second layer. Finally the steel 
plate box is placed inside a wooden box having gross dimensions of $0.85 \mathrm{~m}$ long, $0.85 \mathrm{~m}$ width of $0.72 \mathrm{~m}^{2}$ area. The walls and bottom was constructed of wooden panels $0.03 \mathrm{~m}$ thick, the space between the bottom and the steel plate box are insulated by one layer of insulating materials is made of glass wool $0.03 \mathrm{~mm}$ thick. Fig. (3.2) The adsorbent bed is made of flat plate stainless steel box, having surface area $0.80 \times 0.80 \mathrm{~m} 2$, three different masses of adsorbent bed of activated carbon Maxsorb III type were packed and sealed inside the steel plate box and between fins. The absorber plate surface and the adsorbent box are made of steel sheet having gross dimensions of $0.82 \mathrm{~m}$ long, $0.82 \mathrm{~m}$ width $(0.67 \mathrm{~m} 2$ area) and $0.001 \mathrm{~m}$ thick painted by a blackboard paint mixed with $50 \%$ by weight of a talc powder i.e. (too fin zinc oxide, nontraditional paint) (Ghanem. 2003). The adsorbent bed was covered with a clear glass 3 $\mathrm{mm}$ thick in single or double form to reduce the reflection of radiation and heat losses by convection, or sheet of polyethylene-plastic plates. In order to guarantee better heat transfer between the front side and the adsorbent, seven fins approximately $0.10 \mathrm{~m}$ a part made of stainless steel are installed inside the adsorbent bed box directly in contact with the bottom side of the absorber plate and the activated carbon to improve the transfer of methanol vapor through the activated carbon layer in desorption and adsorption process, a parallel stainless steel sheet bottom $0.001 \mathrm{~m}$ thick is uniformly perforated and installed in the adsorbent bed to permit uniform distribution of methanol in the adsorbent. For the flow of refrigerant (methanol) from the bed a hole is made at the third lower side of bed and coupling is made to connect copper tube of condenser to the bed. The schematic diagram of the adsorbent bed is shown in Fig.(3.3)

\section{Condenser}

The condenser function in the system is to condense vaporized methanol flows from bed to condenser through copper tube and cooling it by air applied on fins of condenser, thus vaporized methanol is converted into liquid methanol. This liquefied methanol now goes to evaporator, It has the following specification:

- Tube material : copper material

- Tube diameter( condenser) : $9.525 \mathrm{~mm}$ 
PROCESS ENGINEERING

- Number of tubes used : 1

- Fin material : Aluminum

- Total number of fins : 14

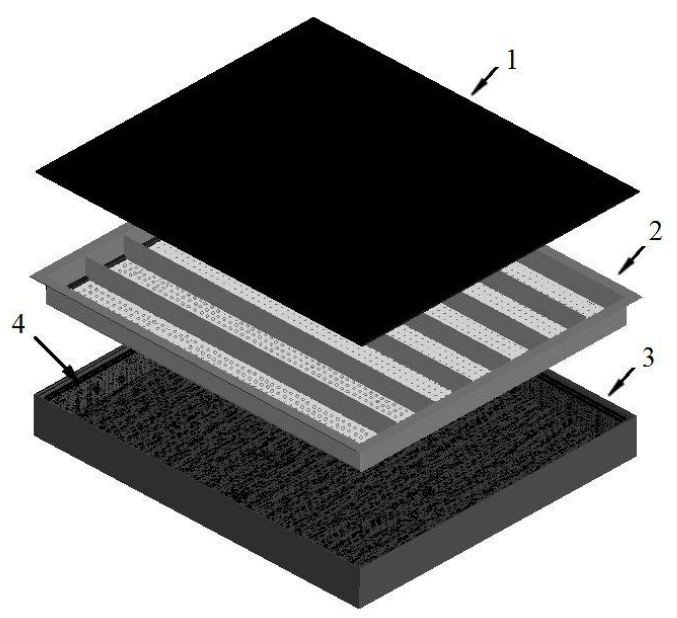

1 Front plate

2 Adsorbent bed

3 Wooden box

4 Insulating materials

Fig. (3.2) Schematic Of The Different Parts Of The Collector.

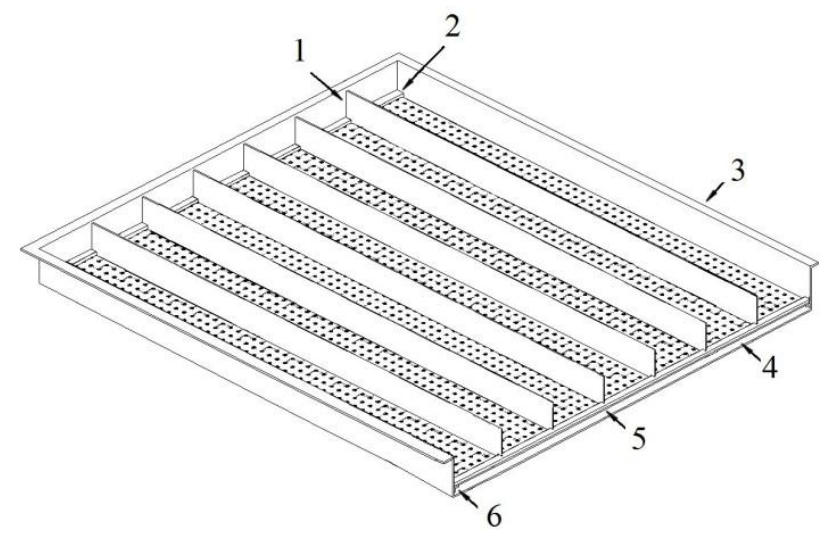

1. Fin.

2 Supporting plate.

3 Flat plate stainless steel box.

4 False bottom

5 Perforated steel plate.

6 Angle (L) install perforated plate.

\section{Fig.(3.3) Schematic Of Adsorbent Bed}




\section{Evaporator}

The evaporator must have sufficient volume to collect the entire condensed methanol. In order to enhance the heat transfer effect, the heat exchange surface is designed as a series of four trapezoidal cells with dimension of $0.3 \mathrm{~m} \times 0.3 \mathrm{~m} \times 0.1 \mathrm{~m}$. Evaporator is made up of stainless steel sheet $0.001 \mathrm{~m}$ thick. The evaporator is placed inside a cooling chamber, the lower portion of evaporator is made up of trapezoidal shape with dimensions of $0.03 \mathrm{~m} \times 0.04 \mathrm{~m}$, to increase surface area and ensures better heat transfer, hole is made on upper side of evaporator to be fitted to the end of the condenser pipe.

\section{Cooling Chamber}

The cooling chamber was constructed of stainless steel sheet $0.0005 \mathrm{~m}$ thick, with dimensions of $0.5 \mathrm{~m}$ long, $0.5 \mathrm{~m}$ wide and $0.5 \mathrm{~m}$ high, the side walls and bottom of cooling chamber were insulated by two insulating materials, the first one is a foam layer $0.05 \mathrm{~m}$ thick, the second is glass wool $0.03 \mathrm{~m}$ thick, all of them were located in a wooden panel box which is made of wooden panels with dimensions of $0.58 \mathrm{~m}$ long and $0.58 \mathrm{~m}$ wide, and $0.58 \mathrm{~m}$ height, The chamber door was made of wooden panels with gross dimensions of $0.58 \mathrm{~m}$ long and $0.58 \mathrm{~m}$ wide, the door was tightly sealed by a rubber gasket.

\section{Methanol}

Methanol also known as methyl alcohol, which is a chemical with the formula $\mathrm{CH}_{3} \mathrm{OH}$, methanol acquired the name "wood alcohol". Methanol used in the present work is made in India purity of $99.8 \%$

\section{Activated Carbon}

The activated carbon Maxsorb III type, and methanol is best suitable pair for the adsorption refrigeration process and also refrigerant methanol has zero ozone depletion potential and very low global worming potential, thus the refrigerator is eco-friendly. The activated carbon is a high density adsorbent and provides maximum volume activity, high hardness and mechanical strength ensures negligible losses during backwashing, air scouring and multiple reactivations. 


\section{Measuring Instruments}

\section{Solar intensity device}

A black and white pyranometer designed, constructed and tested by Ghanem (1989) and calibrated in the Solar Energy Department, National Research Center (NRC), Giza, Egypt. It was used to measure the instantaneous total solar radiation incident on the horizontal plain as shown in Fig. (3.4). The output voltage of the pyranometer is converted to solar intensity as one $\mathrm{mV}$. equal to $182.6 \mathrm{~W} / \mathrm{m}^{2}$.

\section{Temperature Sensors}

Temperatures were measured using LM 35 sensors. The LM35 series are precision integrated-circuit temperature sensors, whose output voltage is linearly proportional to the Celsius (Centigrade) temperature. The LM35 does not require any external calibration their accuracies are $\pm 1 / 4^{\circ} \mathrm{C}$ at room temperature and $\pm 3 / 4^{\circ} \mathrm{C}$ over a full -55 to $+150^{\circ} \mathrm{C}$ temperature range, Fig. (3.5) Temperatures were measured in ten points: front and rear face of the collector, on condenser, on evaporator and the cold chamber.

The LM 35 temperature sensors are connecting to the 10 way selector switch as shown in Fig. (3.6) in order to facilitate the transition between the measuring points. Their specifications are:

- 10 way selections to 1 output

- Plastic screw spacers

- Up to 5A current rating for each input

- Can be used for selection data or power signals

- $\quad$ Size: $75 \times 65 \mathrm{~mm}$

The outlet of selector switch and the positive terminal are connecting to digital multimeter as shown in Fig. (3.7) to read the system temperatures.

\section{VANE Meter}

The ambient temperature in ${ }^{\circ} \mathrm{C}$, relative humidity (\%) and air velocity were measured using VANE type anemometer, 3 in one, professional,

\section{Pressure Gauge}

The system pressure can be measured between the collector and the condenser during desorption time and between the collector and the 
evaporator at adsorption process by glycerin Pressure gauge type, this device was made in china.

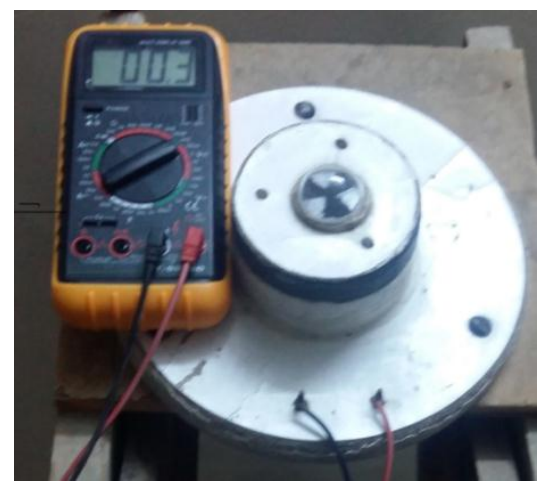

Fig. (3.4): The solar meter

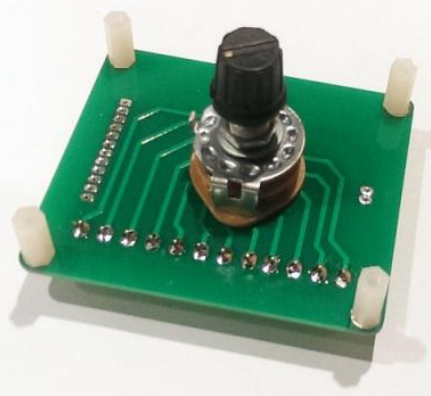

Fig (3.6): Selector Switch

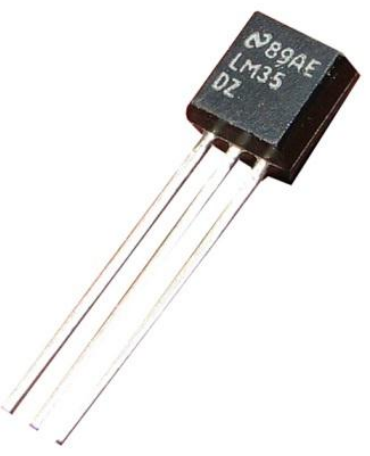

Fig (3.5): The LM 35 Sensors

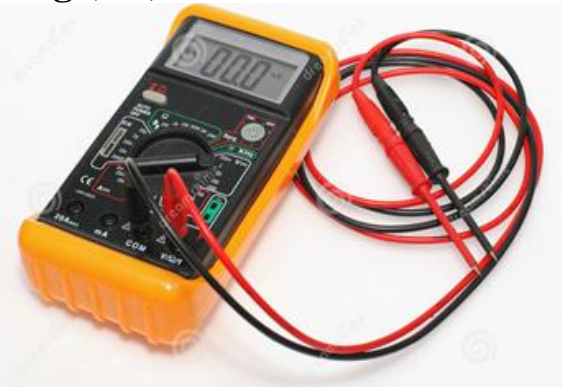

Fig (3.7): The Digital Multimeter

\section{METHODS}

In the present work some engineering factors affecting the performance of solar adsorption refrigerator were studied follows:

\section{Collector efficiency calculations}

The amount of solar radiation received by the collector is:

$$
\mathbf{Q}_{\mathbf{i}}=\mathbf{I} \boldsymbol{\tau} \propto \mathbf{A}
$$

Where:

$\boldsymbol{I}=$ the intensity of solar radiation, in $\mathrm{W} / \mathrm{m} 2$,

$\boldsymbol{A}=$ a collector surface area, in $\mathrm{m} 2$

$\boldsymbol{\tau}=$ is the transmittance of collector cover,

$\propto=$ is the absorption of plate collector.

The rate of heat loss $(\mathrm{QL})$ depends on the collector overall heat transfer coefficient (UL) and the collector temperature. 


$$
\mathbf{Q}_{\mathbf{L}}=\mathbf{U}_{\mathbf{L}} \mathbf{A}\left(\mathbf{T}_{\mathbf{p}}-\mathbf{T}_{\mathrm{a}}\right)
$$

Where:

$$
\begin{aligned}
& \boldsymbol{T}_{\boldsymbol{p}}=\text { average Flat-plate collector temperature, }{ }^{\circ} \mathrm{c}, \\
& \boldsymbol{T}_{\boldsymbol{a}}=\text { ambient temperature, }{ }^{\circ} \mathrm{c}, \text { and } \\
& \boldsymbol{U}_{\boldsymbol{L}}=\text { the collector overall heat transfer coefficient, } \mathrm{W} / \mathrm{m} 2 .{ }^{\circ} \mathrm{c}
\end{aligned}
$$

The overall heat transfer coefficient of the collector UL is expressed by

$$
\mathbf{U}_{\mathbf{L}}=\mathbf{U}_{\mathbf{T}}+\mathbf{U}_{\mathbf{B}}+\mathbf{U}_{\mathbf{S}}
$$

Where $U_{T}, U_{B}$ and $U_{S}$ are the heat losses coefficients of the top, bottom and sides of the collector (generator/absorber), respectively. Since $U_{S}$ is too small it can be neglected (Qasem and El-Shaarawi, 2013) $U_{T}$ is calculated according to Duffie and Beckman, 2013.

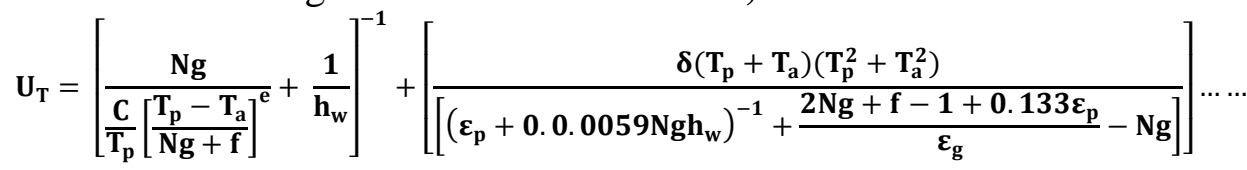

Where:

$N_{g}=$ number of glass covers

$\boldsymbol{f}=(1+0.089 \mathrm{hw}-0.1166 \mathrm{hw \varepsilon p})(1+0.07866 \mathrm{Ng})$

$C=520(1-0.000051 \beta 2)$ for $0 \circ<\beta<70^{\circ}$; for $70^{\circ}<\beta<90^{\circ}$, use $\beta=70^{\circ}$

$\boldsymbol{e}=0.430(1-100 / \mathrm{Tp})$

$\boldsymbol{\beta}=$ collector tilt $(27.32 \mathrm{o})$

$\varepsilon_{g}=$ emittence of glass and plastic sheet are $0.88,0.90$ respectively.

$\varepsilon_{p}=$ emittence of plate

$\boldsymbol{T}_{\boldsymbol{a}}=$ ambient temperature $\left({ }^{\circ} \mathrm{c}\right)$

$\boldsymbol{T}_{\boldsymbol{p}}=$ mean plate temperature $\left({ }^{\circ} \mathrm{c}\right)$

$\boldsymbol{\delta}=$ Stefan-Boltzman constant $\left(5.6704 \times 10-8 \mathrm{~W} / \mathrm{m} 2{ }^{\circ} \mathrm{c} 4\right)$

$\boldsymbol{h}_{\boldsymbol{w}}=$ wind heat transfer coefficient $\left(\mathrm{W} / \mathrm{m} 2^{\circ} \mathrm{c}\right)$. And equal $\boldsymbol{h}_{\boldsymbol{w}}=5.7+3.8 \mathrm{~V}$ when the wind speed equal to $5 \mathrm{~m} / \mathrm{s}$ and when it was more than $5 \mathrm{~m} / \mathrm{s}$ the following equation following can be used $\mathrm{h}_{\mathrm{w}}=7.44\left(\mathrm{v}^{0.8}\right)$ The back losses coefficients UB depend on the insulation material and its thickness which can be evaluated by:

$$
\mathbf{U}_{\mathbf{B}}=\frac{\mathbf{K}_{\mathbf{s}}}{\mathbf{L}_{\mathbf{s}}}
$$

Where:

$\mathrm{Ks}=$ Thermal conductivity of the insulation material. $\mathrm{W} / \mathrm{m} .{ }^{\circ} \mathrm{c}$, and 
Ls $=$ The thickness of the insulation material, $\mathrm{mm}$

Thus, the rate of useful energy extracted by the collector $\mathrm{Qu}$ expressed as a rate of extraction under steady state conditions is equal amount lost by the collector to its surroundings sub stracted form the rate of useful energy absorbed by the collector, less the. This is expressed as follows:

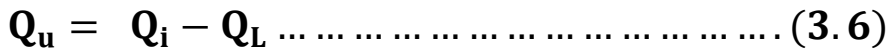

$$
\begin{aligned}
& =\mathbf{I} \boldsymbol{\tau} \propto \mathbf{A}-\mathbf{U}_{\mathbf{L}} \mathbf{A}\left(\mathbf{T}_{\mathbf{p}}-\mathbf{T}_{\mathbf{a}}\right)
\end{aligned}
$$

Useful heat of the collector can also be measured by the amount of heat carried away by the fluid i.e methanol desorbed by activated carbon and passed through the condenser vice versa as,

$$
\mathbf{Q}_{\mathbf{u}}=\mathbf{m} \mathbf{C p}\left(\mathbf{T}_{\mathbf{p}}-\mathbf{T}_{\mathbf{i}}\right)
$$

Where:

$$
\boldsymbol{T}_{\boldsymbol{i}} \text { inlet fluid temperature, }{ }^{\circ} \mathrm{C}
$$

Using equation (3.9) heat removal factor of the system FR can be found as follows:

$$
F_{R}=\frac{m C p\left(T_{p}-T_{i}\right)}{A\left[I \tau \propto-U_{L}\left(T_{p}-T_{a}\right)\right]}
$$

The maximum possible useful energy gain in a solar collector occurs when the whole collector is at the inlet fluid temperature. The actual useful energy gain $Q_{u}$, is found by multiplying the collector heat removal factor FR by the maximum possible useful energy gain. This allowed by rewriting of equation (3.8) as:

$$
\mathbf{Q}_{\mathbf{u}}=\mathbf{F}_{\mathbf{R}} \mathbf{A}\left[\mathbf{I} \tau \propto-\mathbf{U}_{\mathbf{L}}\left(\mathbf{T}_{\mathbf{i}}-\mathbf{T}_{\mathbf{a}}\right)\right]
$$

Equation (9) is a widely used for measuring collector energy gain and is generally known as the "Hottel Whillier-Bliss equation" ( Smith., Weiss.1977)

The collector efficiency $\eta$ defined as the ratio of the useful energy gain $\mathrm{Qu}$ to the incident solar energy over a particular time period:

$$
\boldsymbol{\eta}=\frac{\int \mathbf{Q}_{\mathbf{u}} \mathbf{d t}}{\mathbf{A} \int \mathbf{I} \mathbf{d t}}
$$

The instantaneous thermal efficiency of the collector is:

$$
\begin{aligned}
& \eta=\frac{\mathbf{Q}_{\mathbf{u}}}{\mathbf{I A}} \ldots \ldots \ldots \ldots \ldots \ldots \ldots \ldots \ldots \ldots \ldots \ldots \ldots \ldots \\
& \eta
\end{aligned}
$$




$$
\eta=\mathbf{F}_{\mathbf{R}} \boldsymbol{\tau} \propto-\mathbf{F}_{\mathbf{R}} \mathbf{U}_{\mathbf{L}}\left(\frac{\mathbf{T}_{\mathbf{i}}-\mathbf{T}_{\mathbf{a}}}{\mathbf{I}}\right) \ldots \ldots \ldots \ldots \ldots
$$

\section{Numerical integration}

Numerical integration used in the present work is derived using Simpson's rule as reported by Toledo (2007), this procedure assumes a parabolic curve between area increments. The curve is divided into an even number of increments, therefore, including the value of the function at the lower and upper limits, (there will be i values of the height of the function and $(i-1)$ area increments. The number of increments $(i-1)$ must be an even integer. Thickness of area increments must be uniform, therefore, for the limits $\mathrm{x}=\mathrm{a}$ to $\mathrm{x}=\mathrm{b}, \Delta \mathrm{x}=(\mathrm{b}-\mathrm{a}) /(\mathrm{i}-1)$. Simpson's rule is as follows:

$$
\begin{aligned}
\int_{a}^{b} f(x) d x=\frac{x}{3} & {[F(a)+4 F(1)+2 F(2)+4 F(3)+2 F(4)+\cdots 2 F(i-2)} \\
& +4 F(i-1)+F(b)] \ldots \ldots \ldots \ldots \ldots \ldots \ldots \ldots \ldots \ldots \ldots \ldots \ldots \ldots
\end{aligned}
$$

\section{Adsorption and desorption calculations}

\section{Adsorption equilibrium}

The adsorption and desorption concentrations (x) are usually determined by Dubinin-Astakhov equation ( Critoph , 1991):

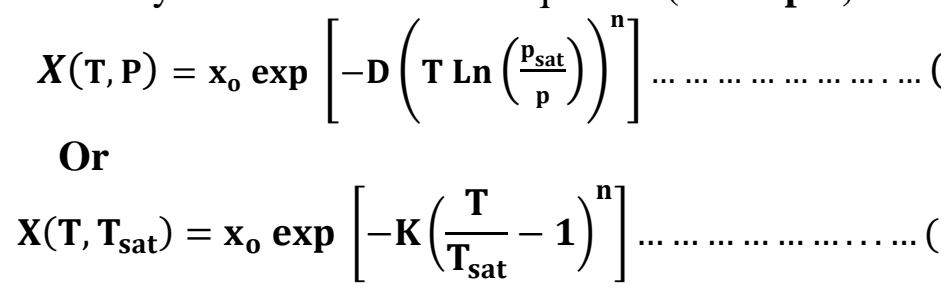

Where:

$\boldsymbol{x}$ concentration ratio of adsorbate inside adsorbent $(\mathrm{kgm} / \mathrm{kgac})$

$\boldsymbol{K}$ adsorbent constant

$\boldsymbol{x}_{\boldsymbol{o}}$ limited adsorption capacity,

D Dubinin-Astakhov constant $\left({ }^{\circ} \mathrm{c}-1\right)$

n Dubinin-Astakhov constant

$\boldsymbol{P}$ system pressure ( $\mathrm{kPa})$

$\boldsymbol{T}$ temperature $\left({ }^{\circ} \mathrm{c}\right)$

Sat saturated

The parameters xo, D, n Special adsorbent material and given especially Table (1) (Qasem and El-Shaarawi 2013) 
Table (3.1): Parameters xo, D, n, $\rho$ and CP in Activated Carbon

\begin{tabular}{ccccccc}
\hline $\begin{array}{c}\text { Activated } \\
\text { carbon }\end{array}$ & $\begin{array}{c}\boldsymbol{x}_{\boldsymbol{o}} \\
\left(\mathbf{k g ~ k g}^{\mathbf{1}}\right)\end{array}$ & $\begin{array}{c}\mathbf{D} \\
\left({ }^{\mathrm{D}} \mathrm{C}^{-\mathbf{1}}\right)\end{array}$ & $\mathbf{n}$ & $\begin{array}{c}\boldsymbol{\rho} \\
\left(\mathbf{K g m}^{-3}\right)\end{array}$ & $\begin{array}{c}\mathbf{C P}_{\mathbf{P}} \\
\left(\mathbf{k J ~ k g}^{-1} \mathrm{C}^{-\mathbf{1}}\right)\end{array}$ & $\mathbf{k}$ \\
\hline Maxsorb III & 1.24 & $4.022 \times 10^{-6}$ & 2.0 & 281 & 0.93 & 13.38 \\
\hline
\end{tabular}

Thermodynamic analysis of the refrigeration cycle

\section{Setp: 1 Isosteric heating process}

In this process the heat absorbed by the solar collector is utilized to heat up the activated carbon $\mathbf{Q}_{\mathbf{A}-\mathbf{B}}$ as shown by a line $\mathrm{A}-\mathrm{B}$, in Clapeyron diagram Fig. (3.8). Thus, the isosteric sensible heat addition is expressed as:

$$
Q_{A-B}=M_{a c}\left(\mathbf{c p m}_{m}+x \mathbf{c p a c}\right)\left(T_{B}-T_{A}\right)
$$

Where:

$\boldsymbol{M}_{\boldsymbol{a}}$ mass of activated carbon $(\mathrm{kg})$.,

$\boldsymbol{C} \boldsymbol{p}_{\boldsymbol{a c}}$, cpm specific heat at constant pressure $\left(\mathrm{kJ} \mathrm{kg}-1{ }^{\circ} \mathrm{c}-1\right)$ that given Table (1)

$\boldsymbol{T}_{\boldsymbol{A}}$ Temperature at point A. This temperature is taken at 8:00 AM session at the start of isosteric heating at adsorbent bed.

$\boldsymbol{T}_{\boldsymbol{B}}$ Temperature at point B, This temperature is taken at 10:00 AM of the day and at the end of isosteric heating and start of desorption process at adsorbent bed. (Nilesh et al. 2014b)

Setp: 2 Isobaric desorption process

The desorption process is represented by the line (B-D). in Fig. (3.8) the heat provided to desorb methanol during this process $\mathrm{Q}_{\mathrm{B}-\mathrm{D}}$ can be written as:

$$
Q_{B-D}=M_{a c}\left(c_{m}+x \text { cpac }\right)\left(T_{B}-T_{A}\right)+M_{a c} \Delta H(\text { XB }- \text { XD }) \ldots . .(3.19)
$$

Where:

$\boldsymbol{x}_{\boldsymbol{B}}$ adsorption capacity at point $\mathrm{B}$, which calculated according to Dubinin-Astakhov equation

XD adsorption capacity at point D. which calculated according to Dubinin-Astakhov equation

$\boldsymbol{\Delta} \boldsymbol{H}$ heat of desorption or adsorption per unit mass of methanol $(\mathrm{kJ} \mathrm{kg}-1)$, it can also be estimated as a function of latent heat (Le) of methanol (Critoph , 1991)

$$
\mathbf{H}=\mathbf{L}_{\mathbf{e}}\left(\frac{\mathrm{T}}{\mathbf{T}_{\mathrm{sat}}}\right)
$$


The summation of the desorption heat together with the isosteric heat is called the generation or regeneration energy and is given as:

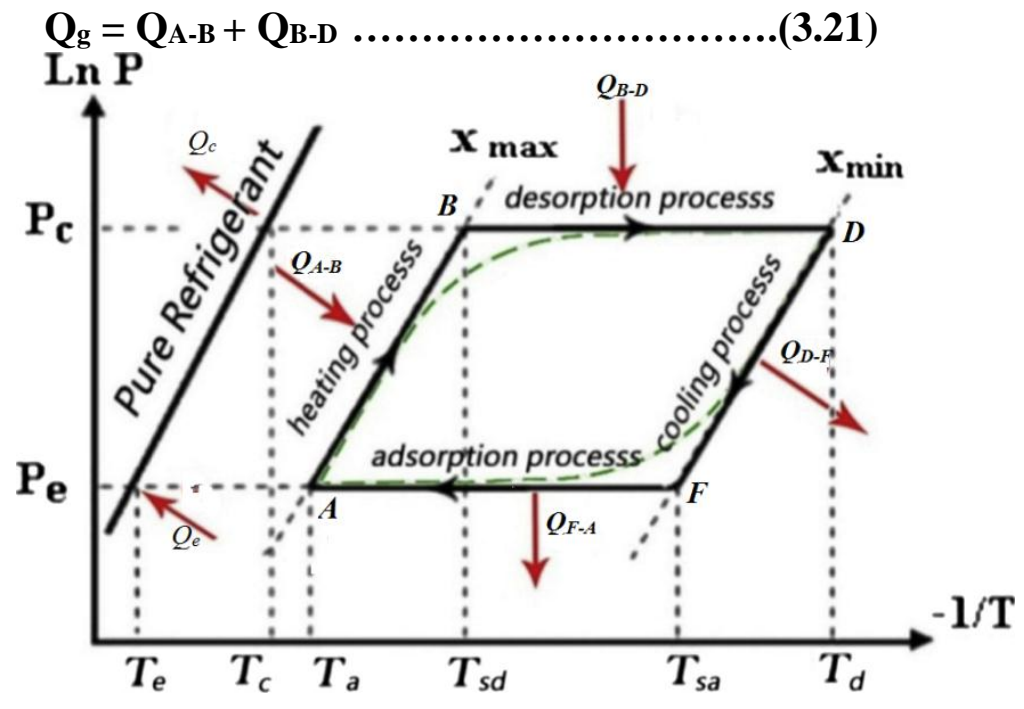

Fig.(3.8). Schematic view of the adsorption process on Clapeyron diagram

\section{Performance calculations for system}

\section{Thermal analysis of evaporator}

The quantity of heat transferred in the evaporator during refrigeration process is:

$$
Q_{\text {eva }}=\operatorname{Le~Mac~} \Delta x
$$

Where:

$\Delta \boldsymbol{x}$ the difference between of the minimum and maximum concentration value ( $\left.\mathbf{x}_{\mathbf{m a x}}-\mathbf{x}_{\mathbf{m i n}}\right)$ which calculated according to Dubinin-Astakhov equation.

\section{The coefficient of performance}

The performance of the refrigeration system alone is described by the coefficient of performance of its cycle (COP) without including the solar collector performance. (Qasem and El-Shaarawi (2013)).

$$
C O P=\frac{Q e v a}{Q_{g}}=\frac{L e M a c \Delta x}{Q_{A-B}+Q_{B-D}}
$$

\section{Refrigeration load}

The refrigeration load is the rate of heat energy removal from a given space (or object) in order to lower the temperature of space to a desired 
level ( Paul Singh and Dennis 2014) The refrigeration load of any product store is made up of the basic components as follow:

- Heat removed form cold room.

$$
\mathrm{Q}_{\mathrm{r}}=\frac{\mathrm{m}_{\mathrm{a}} \mathrm{c}_{\mathrm{p}}\left(\mathrm{T}_{\mathrm{o}}-\mathrm{T}_{\mathrm{i})}\right.}{\mathrm{t}}
$$

Where:

$Q_{r}$ heat removed form cold room $\mathrm{kW}$,

$\boldsymbol{m}_{\boldsymbol{a}}$ mass of air inside cold room,

$\boldsymbol{C p}$ specific heat of air $\mathrm{kJ} / \mathrm{kg} .{ }^{\circ} \mathrm{c}$,

$\boldsymbol{T}_{\boldsymbol{o}}$ temperature of air outside the refrigerator ${ }^{\circ} \mathrm{c}$, and

$\boldsymbol{T}_{\boldsymbol{i}}$ temperature of air inside the refrigerator ${ }^{\circ} \mathrm{C}$

- Heat leakage ( conduction through)

$$
\mathbf{Q L}=\mathbf{U} \mathbf{A}(\mathbf{T o}-\mathbf{T i})
$$

$Q_{\text {Ref. load }}=Q_{\mathrm{r}}+\mathbf{Q}_{\mathrm{L}}$

Where:

$Q_{L}$ rate of heat transmitted through wall, $\mathrm{kW}$.,

$\boldsymbol{U}$ overall head coefficient $\mathrm{kW} / \mathrm{m} 2 .{ }^{\circ} \mathrm{c}$.,

$\boldsymbol{A}$ surface area of refrigeration unit $\mathrm{m} 2$.,

$\boldsymbol{T}_{\boldsymbol{o}}$ temperature of air outside the refrigerator ${ }^{\circ} \mathrm{c}$, and

$\boldsymbol{T}_{\boldsymbol{i}}$ temperature of air inside the refrigerator ${ }^{\circ} \mathrm{c}$.

\section{RESULTS AND DISSCUSIONS}

Effect of collector cover material on collection efficiency as affected by ambient conditions

\section{Solar intensity and ambient conditions}

For evaluating the effect of cover material on collection efficiency of the solar collector or generator ambient conductions were measured: hourly solar intensity, ambient temperatures and wind speeds respectively. Fig.(4.1),(4.2) showed solar intensity and ambient air temperature distribution as affected by local time during refrigerator testing. It is clear that solar intensity has a trend of approximately normal distribution curve before noon and afternoon, due to the physical phenomena of the nature of the solar radiation and the measuring instrument as it is electromagnetic flux. Maximum values of the solar intensity were at the noon time ranged between $1.0-1.24 \mathrm{~kW} / \mathrm{m}^{2}$ and minimum values at morning and afternoon which are ranged between $0.51-0.73 \mathrm{~kW} / \mathrm{m}^{2}$ and 
0.39- $0.65 \mathrm{~kW} / \mathrm{m}^{2}$ before and after noon respectively. It is also clear that ambient air temperature do not obey the normal distribution trend curve as solar intensity which may be interpreted by the interaction of various effects between ambient air humidity and wind speeds.

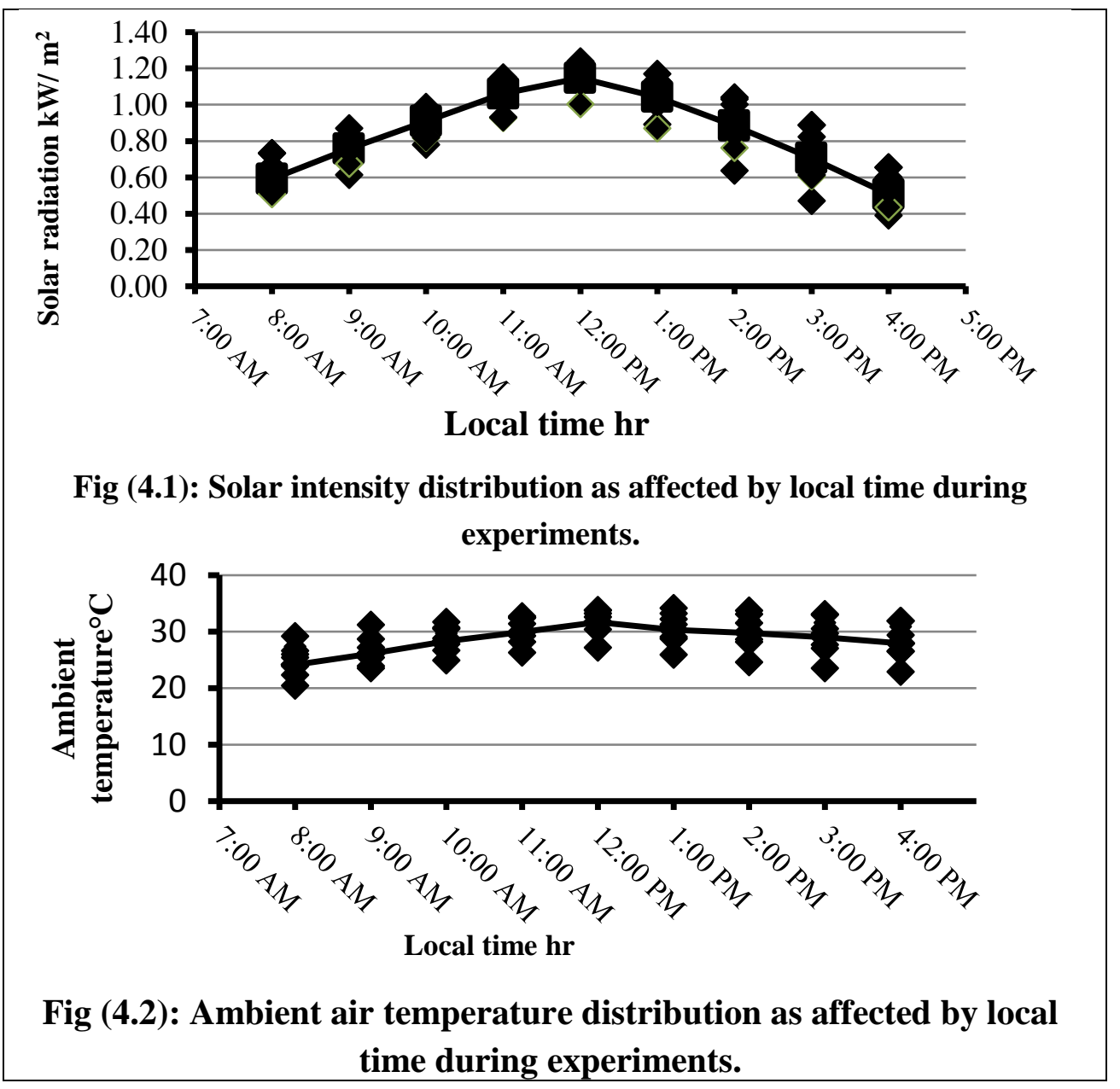

\section{Solar collector efficiency as affected by cover material type}

In present study three different cover materials namely: single glazing, double glazing and polyethylene-plastic sheet were tested. Fig (4.3) showed the effect of cover material on thermal efficiency of the collector or generator as affected by local time. It is clear that double glass cover material has the highest average efficiency $39.83 \%$ compared to $30.27 \%$ and. $30.22 \%$ for both single and polyethylene-plastic sheet respectively. 
That may be interpreted by lower total daily heat losses and higher total daily useful heat $0.922 \mathrm{~kW} /$ day and $2.671 \mathrm{~kW} /$ day of double glazing compared to $1.116,1.165 \mathrm{~kW} /$ day and $1.522,1.961 \mathrm{~kW} /$ day for both single glass and polyethylene cover respectively. Previously results discussed may be interpreted by stagnant insulation of air gap between the two consecutive glass covers than that of one glass cover or polyethyleneplastic sheet as depicted in Figs.(4.4) and (4.5) respectively.

Thermal efficiency of single, double glazing and polyethylene plastic sheet cover were decreased form morning to afternoon. Thermal efficiencies of both single and polyethylene-plastic cover were approximately the same for all same local time form morning to afternoon. The Maximum and minimum average efficiency values for both single and polyethylene plastic covers ranged between 33.41 to $27.98 \%$ for all local day times with standard deviation ranged between 1.13 to 0.01 and too small coefficient of variation ranged between 0.0337 to 0.0003.Comparing double glazing with average values of both single and polyethylene plastic covers based on thermal efficiency increment percent as:

$$
\eta_{\text {Increment }}=\frac{\eta_{\text {Double }-\eta_{\text {avg. }}}}{\eta_{\text {avg. }}}
$$

Data showed that the maximum and minimum efficiencies of the double glass cover collector were increased from 42.83 to $35.89 \%$ than that of both single and polyethylene cover respectively. From previous discussion, it is clear that the double glazing cover is the optimal cover material of all studied cover materials in present work.

\section{Effect of adsorbent mass load on the refrigeration performance Evaluating the effect of carbon mass on the coefficient of performance of the refrigerator}

Table (4.1), Fig. (4.6) showed that the coefficient of the performance C.O.P \% of the double glazing collector for all studied carbon mass materials tested were increased linearly by increasing the average daily solar radiation calculated using the Simpson rule for numerical integration and satisfied only with the range of 6.6 to $7.9 \mathrm{~kW} \cdot \mathrm{hr} / \mathrm{m} 2 /$ day. It is also clear that there is a direct proportion between the COP $\%$ and the average daily solar radiation. Higher values of COP \% were recorded 
for the $14 \mathrm{~kg}$ carbon mass than that of 12 and $16 \mathrm{~kg}$ carbon mass respectively, these results agreed with that reported by Qasem and ElShaarawi (2013),

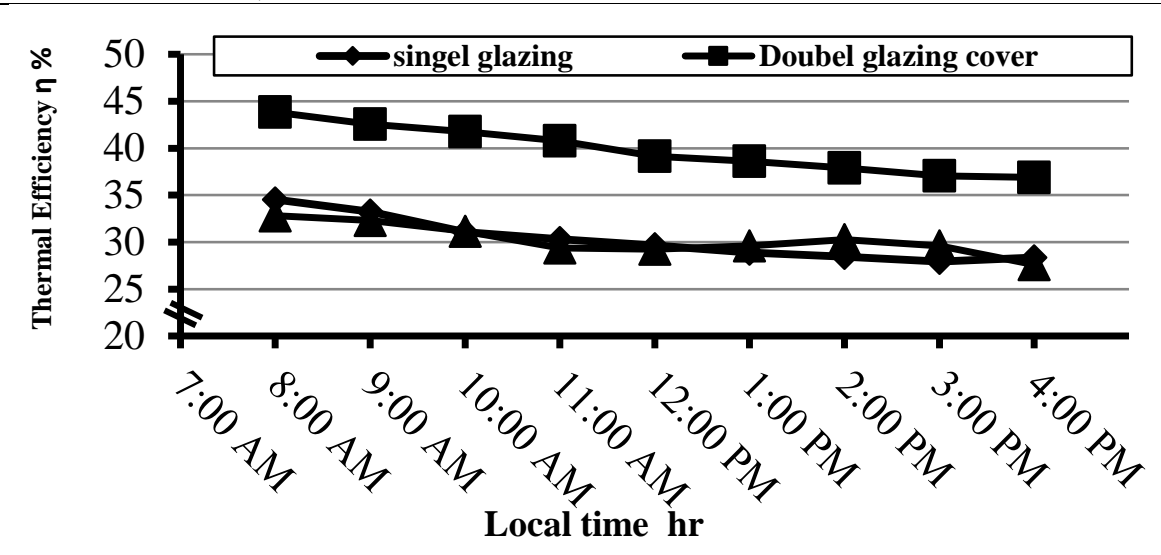

Fig (4.3): Solar collection efficiency as affected by caver material type.
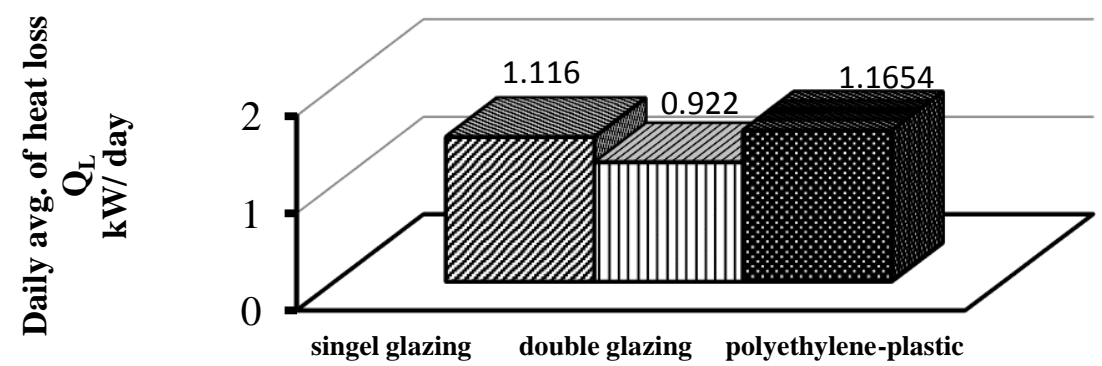

Fig(4.4):Comparing heat losses of single, double glazing and polyethyleneplastic sheet cover.
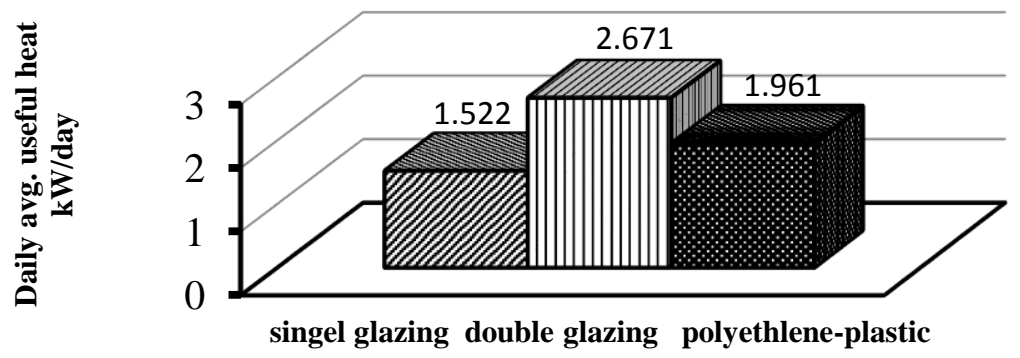

Fig(4.5):Comparing useful heat, of single, double glazing and polyethyleneplastic sheet 
that increasing desorption material mass has a negative effect on the COP $\%$ and there is an optimal mass of the adsorbent material required for a defined methanol quantity and the quantity for the best C.O.P $\%$ is recorded as $14 \mathrm{~kg}$ mass of the adsorbent bed material which is an optimal quantity compatible to $3.4 \mathrm{~kg}$ of methanol.Satisfied equations for the effect of carbon mass and daily solar radiation in $\mathrm{kW} . \mathrm{h} / \mathrm{m}^{2}$. day on coefficient of performance are follows:

$$
\text { COP }_{12 \mathrm{~kg} \text { car. }}=0.1089 \mathrm{I}_{\mathrm{d}}-0.411 \quad \mathrm{R}^{2}=0.994 .
$$

With total daily solar radiations ranged 6.6 to $7.6 \mathrm{~kW} . \mathrm{h} / \mathrm{m}^{2}$.day.

$$
\text { COP }_{14 \mathrm{kgcar} .=0.0486} \mathrm{I}_{\mathrm{d}}+\mathbf{0 . 1 3 5} \quad \mathbf{R}^{\mathbf{2}}=\mathbf{0 . 9 5 4}
$$

With total daily solar radiations ranged 6.6 to $7.7 \mathrm{~kW} . \mathrm{h} / \mathrm{m}^{2}$.day.

$$
\text { COP } 16 \text { kg car. }=0.031 I_{d}+0.0467 \quad R^{2}=0.911
$$

With total daily solar radiations ranged 6.8 to $7.9 \mathrm{~kW} . \mathrm{h} / \mathrm{m}^{2}$.day.

Table (4.4):Effect the total daily solar radiation, and adsorbent material mass on coefficient of performance.

\begin{tabular}{|c|c|c|c|c|c|}
\hline \multicolumn{7}{|c|}{ Double glazing cover } \\
\hline \multicolumn{2}{|c|}{$\mathbf{1 2}$ kg carbon } & \multicolumn{2}{|c|}{$\mathbf{1 4}$ kg carbon } & \multicolumn{2}{|c|}{$\mathbf{1 6} \mathbf{~ k g}$ carbon } \\
\hline $\begin{array}{c}\mathbf{I}_{\mathbf{d}} \\
\mathbf{k W} \cdot \mathbf{h} / \mathbf{m}^{2} \text {.day }\end{array}$ & $\mathbf{C O P}$ & $\begin{array}{c}\mathbf{I}_{\mathbf{d}} \\
\mathbf{k W . h} / \mathbf{m}^{2} . \mathbf{d a y}\end{array}$ & $\mathbf{C O P}$ & $\begin{array}{c}\mathbf{I}_{\mathbf{d}} \\
\mathbf{k W} \cdot \mathbf{h} / \mathbf{m}^{2} . \mathbf{d a y}\end{array}$ & $\mathbf{C O P}$ \\
\hline 6.6 & 0.304 & 6.6 & 0.453 & 6.8 & 0.277 \\
\hline 6.9 & 0.345 & 6.9 & 0.471 & 7.2 & 0.289 \\
\hline 7.2 & 0.372 & 7.1 & 0.488 & 7.4 & 0.306 \\
\hline 7.6 & 0.415 & 7.7 & 0.507 & 7.9 & 0.313 \\
\hline
\end{tabular}

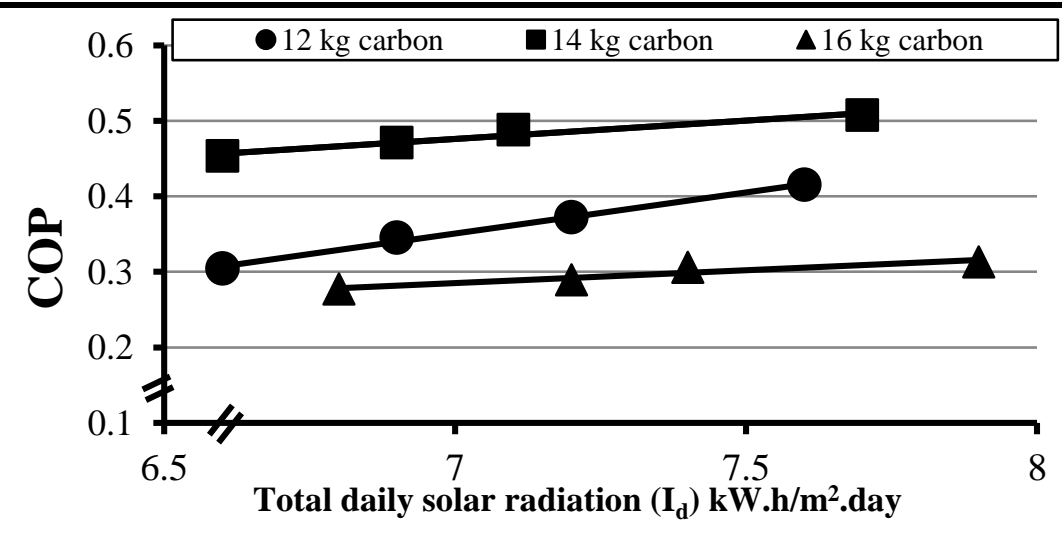

Fig.(4.6):Effect the total daily solar radiation, and adsorbent material mass on coefficient of performance 


\section{Effect of the adsorbent bed mass on the refrigeration load}

The effect of the three different adsorbent bed masses 12,14 , and $16 \mathrm{~kg}$ activated carbon were evaluated on the refrigeration load. $\mathbf{R}_{\mathbf{L}}$ in ton ref. Table (4.2) and Fig (4.7) showed that the refrigeration load of the double glazing collector for all studied carbon mass materials tested were increased linear by increasing the average daily solar radiation calculated using the Simpson rule for numerical integration and satisfied only with the ranged 6.6 to $7.9 \mathrm{~kW} . \mathrm{hr} / \mathrm{m} 2 /$ day. It is also clear that there is a direct proportion between the refrigeration load and the average daily solar radiation. Higher values of refrigeration load were recorded for the $14 \mathrm{~kg}$ carbon mass than that of 12 and $16 \mathrm{~kg}$ carbon mass respectively, so it can be concluded that $14 \mathrm{~kg}$ mass of the adsorbent bed material is an optimal quantity compatible to $3.4 \mathrm{~kg}$ of methanol.

Table (4.2): Effect the daily solar radiation, and adsorbent material mass on refrigeration load.

\begin{tabular}{|c|c|c|c|c|c|}
\hline \multicolumn{6}{|c|}{ Double glazing cover } \\
\hline \multicolumn{2}{|c|}{$12 \mathrm{~kg}$ carbon } & \multicolumn{2}{|c|}{$14 \mathrm{~kg}$ carbon } & \multicolumn{2}{|c|}{$16 \mathrm{~kg}$ carbon } \\
\hline $\begin{array}{c}\mathbf{I}_{\mathbf{d}} \\
\mathrm{kW} \cdot \mathrm{h} / \mathrm{m}^{2} / \mathrm{day}\end{array}$ & $\begin{array}{l}\text { Ref. load } \\
\text { ton ref. }\end{array}$ & $\begin{array}{c}\mathbf{I}_{\mathbf{d}} \\
\mathrm{kW} \cdot \mathbf{h} / \mathrm{m}^{2} / \mathrm{day}\end{array}$ & $\begin{array}{l}\text { Ref. load } \\
\text { ton ref. }\end{array}$ & $\begin{array}{c}I_{d} \\
k W \cdot h / m^{2} / \text { day }\end{array}$ & $\begin{array}{c}\text { Ref. load } \\
\text { ton ref. }\end{array}$ \\
\hline 6.6 & 0.03488 & 6.6 & 0.044916 & 6.8 & 0.040593 \\
\hline 6.9 & 0.036724 & 6.9 & 0.046116 & 7.2 & 0.042484 \\
\hline 7.2 & 0.037777 & 7.1 & 0.046793 & 7.4 & 0.044113 \\
\hline 7.6 & 0.039136 & 7.7 & 0.048108 & 7.9 & 0.044782 \\
\hline
\end{tabular}

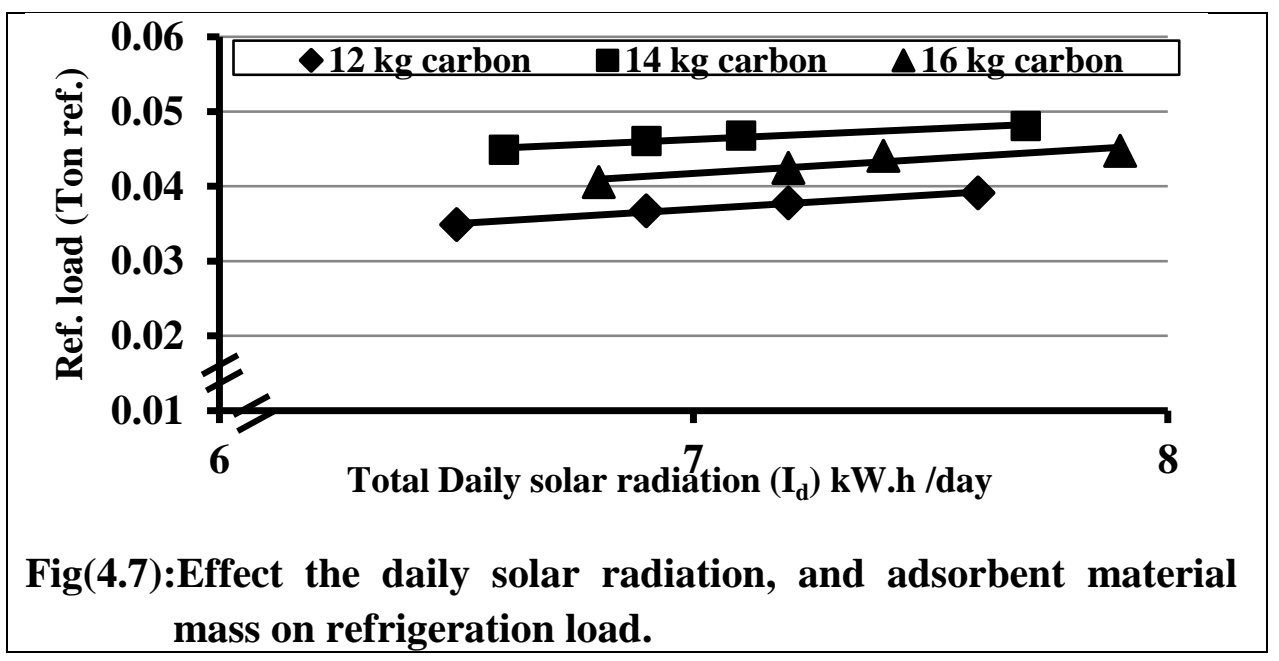


Satisfied equations for the effect of carbon mass and daily solar radiation in $\mathrm{kW} . \mathrm{h} / \mathrm{m}^{2} /$ day on refrigeration load. are follows:

$$
R L_{12 k g \text { car. }}=0.0038 I d+0.01 \quad R^{2}=0.993
$$

With the range between 6.6 to $7.6 \mathrm{~kW} . \mathrm{h} / \mathrm{m} 2 /$ day.

$$
R L_{14 k \text { car }}=0.0028 I d+0.0265 \quad R^{2}=0.973
$$

With the range between 6.6 to $7.7 \mathrm{~kW}$. h/ m2/ day.

$$
R L_{16} \mathrm{~kg}_{\mathrm{car}}=0.00391 \mathrm{~d}+0.0146 \quad R^{2}=0.9031 .
$$

With the range between 6.8 to $7.4 \mathrm{~kW} . \mathrm{h} / \mathrm{m} 2 /$ day.

\section{CONCLUSION}

Solar adsorption refrigeration devices are of significance to meet the needs for cooling requirements such as air-conditioning, ice-making and medical or food preservation in remote areas. They are also noiseless, non-corrosive and environmentally friendly. Various solar powered cooling systems have been tested extensively; however, these systems are not yet ready to compete with the well-known vapor compression system. For these reasons, research activities in this sector are still increasing to solve the technical, economic and environmental problems.

The main results of this research work can be summarized as follows:

1. The solar intensity and ambient air temperature distribution as affected by local time during refrigerator testing. It is clear that solar intensity has a trend of approximately normal distribution curve before noon and after noon, due to the physical phenomena of the nature of the solar radiation and the measuring instrument as it is electromagnetic flux.

2. Three different collector cover materials, single or, double glazing and Polyethylene-plastic cover materials. the double glass cover material has the largest efficiency than both of single and polyethylene-plastic sheet that may be interpreted by lower heat losses and higher useful 
heat due to stagnant insulation of air gap between the two consecutive glass covers. it is clear that the double glazing cover is the optimal cover material of all studied cover materials in present work.

3. The effect of the three different adsorbent bed masses 12,14 , and 16 $\mathrm{kg}$ activated carbon were evaluated on the coefficient of performance and the refrigeration load. RL in ton ref. Higher values of C.O.P \% and the refrigeration load. RL in ton ref. were recorded for the $14 \mathrm{~kg}$ carbon mass than that of 12 and $16 \mathrm{~kg}$ carbon mass respectively, there is an optimal mass of the adsorbent material required for a defined methanol quantity and the quantity for the best C.O.P \% and the refrigeration load. are recorded as $14 \mathrm{~kg}$ mass of the adsorbent bed material which is an optimal quantity compatible to $3.4 \mathrm{~kg}$ of methanol.

\section{REFERENCES}

Critoph RE.(1991). Adsorption refrigerators and heat pump. In: Carbon materials for advanced technologies, Chap 10, Burchell TD (editor); p. 303-40, ISBN 0- 08-042683-2.

\section{Darwesh, M., A.H. Elmetwalli.,A. Derbala, A. Elmetwalli, T. Fouda} and M. Morad, (2010). Manufacture and performance evaluation of solar absorption refrigeration unit for potato storage. The 17th. Annual Conference of the Misr Society of Ag. Eng., 28 October, 2010 pp 1907:1921

Duffie, J. A., and Beckman, W. A. (2013). Solar engineering of thermal processes. John Wiley and Sons.

El Awady, M.N., Abd El-Salam, M.F., Farrag, A.E. and Aboelghait K.M. (2015). Low quality water treatment and deselimation abased on solar energy technology .Misr J. Ag. Eng., 32(2):909-626

El-Metwally, M. (2005). Sunshine and global solar radiation estimation at different sites in Egypt. Journal of Atmospheric and Solar- 
Terrestrial Physics, 67(14), 1331-1342. Cited by Hameed, M. S., (2011)

Ghanem, T. H. (1989). Design of a solar dryer for agricultural products. M.Sc. Th., Fac. of Agric. Al-Azher. U. 50-51

Ghanem, T. H. (2003). Improving Thermal Efficiency of A Flat Plate Solar Collector Using Nontraditional Coating Under Quasisteady conditions. Misr J. Ag. Eng, 20(2), 498-514.

Li, M., Wang, R. Z., Xu, Y. X., Wu, J. Y., and Dieng, A. O. (2002). Experimental study on dynamic performance analysis of a flat-plate solar solid-adsorption refrigeration for ice maker. Renewable energy, 27(2), 211-221.

Nilesh T., U. Dhokane, Savita, Shinde, and M. V. Nagarhalli,(2014)b Performance Evaluation of Intermittent Solid Adsorption Refrigeration System Running On Solar Energy. International Journal of Innovative Research in Science, Engineering and Technology. $3: 79-86$

Qasem, N. A., \& El-Shaarawi, M. A. (2013). Improving ice productivity and performance for an activated carbon/methanol solar adsorption ice-maker. Solar Energy, 98, 523-542.

Smith, C. C., and Weiss, T. A. (1977). Design application of the HottelWhillier-Bliss equation. Solar energy, 19(2), 109-113.

Toledo T. (2007)Fundamentals of Food Process Engineering Third Edition Department of Food Science and Technology University of Georgia page 42

Wang, R. Z., Li, M., Xu, Y. X., and Wu, J. Y. (2000). An energy efficient hybrid system of solar powered water heater and adsorption ice maker. Solar Energy, 68(2), 189-195. 
PROCESS ENGINEERING

\section{الملخص العربي \\ بعض العوامل الهندسة المؤثرة على أداء دورة تبريد

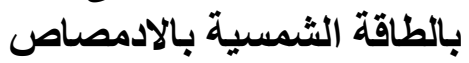

د/ طارق حسين غانم * د/ محمد محمد إبراهيم بلر ** د د/ هدى سعيد حافظ ** م م / أحمد صلاح عيسى ****

تعتبر الطاقة الثمسية من اهم مصادر الطاقات الجديدة والمتجددة والبديلة للوقودالاحفورى. وتبو أت الطاقة الثمسية مكانًا مهما ضمن البدائل المتعلقة بالطاقات المتجددة، وتأتي أهمبتها بأنها مصدراً نظيفاً للطاقة من حيث تأثير ها على البيئة وهي طاقة مباشرة وسهلة الاستخدام متجددة ومستمرة الحفاظ على نفس الجودة ولا تخضع لاحتكار الشركات أو المستثمرين بل بمكن أن ونى

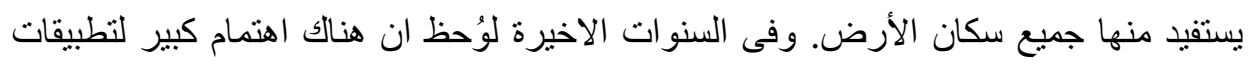
الطاقة الثمسية فى تكنولوجيا التبريد حيث ان التبريد اصبح ضروريا لحفظ المنتجات الزرعية و المواد الغذائية والادوية الطبية و اللقاحات و التحصينات البيطرية وتبريد المنشأت الزراعية. و نظام التبريد بالطاقة الثمسية بالادمصاص و احد من أهم الطرق الواعدة فى التبريد بأستخدام الطاقة الثمسية و التى يمكن ان يلبى الاحتياجات الخاصة بالتبريد مثل تكييف الهواء وصناعة الهن الثلج وحفظ المواد الغذائية والمواد الطبية واللقاحات و التحصينات البيطرية وخصوصا فى لئ المناطق النائية والمستصلحة حديثا ونظر ا لما له من مزايا أهمها أنه أمان تماماً على البيئة إنخفاض تكلفة الصيانة و الاصلاحات غير قابلة للتأكل و لا يحدث منها ضوضاء. ويهدف هذا البحث الى :

ا . أنشاء وتصنيع وحدة تبريد بالطاقة الثمسية بالادمصاص باستخدام زوج العمل كربون نشط

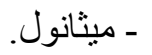
ץ. در اسـة بعض العوامل الهندسية التى تؤثر على أداء الدورة للوصول لافضل أداء ـوحمولة التبريد ب. در اسة أقتصادية

* (استاذ بقسم هندسة تصنيع المنتجات الزراعية بكلية الهندسة الزراعية - جامعة الازهر بالقاهرة . ** أستاذ مساعد بقسم هندة تصنيع المنتجات الزراعية ـ كلية الهندسة الزراعيةـ جامعة الأزهر- القاهرة. ****أستاذ الكيمياء النانوضوئية المساعد - معهد الدراسات والبحوث البيئية - جامعة مدينة السـادات. ****مدرس مساعد بقسم هندسة تصنيع المنتجات الزراعية بكلية الهندسة الزراعية - جامعة الازهر بالقاهرة. 


\section{وقد أظهرت النتائج ما يلى :}

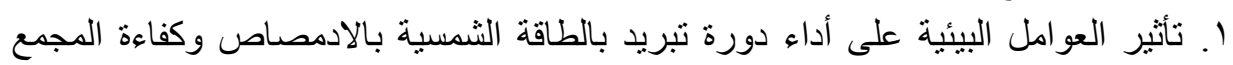

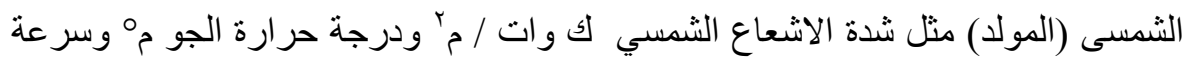

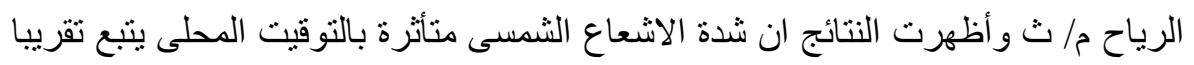

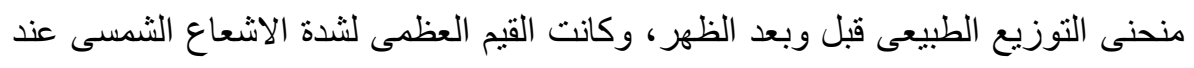

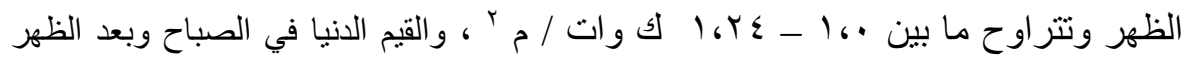

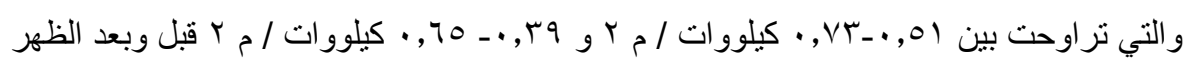

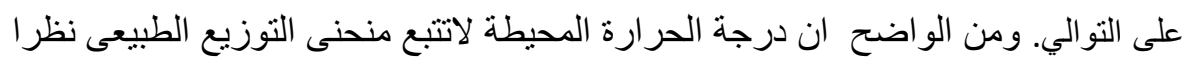

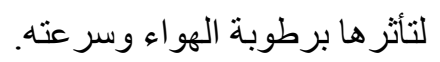

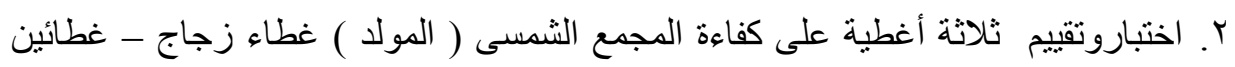

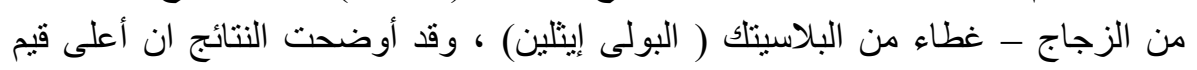

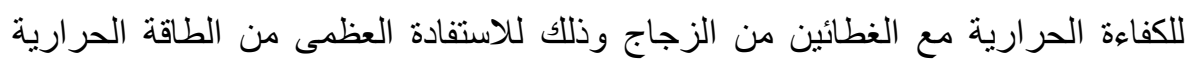

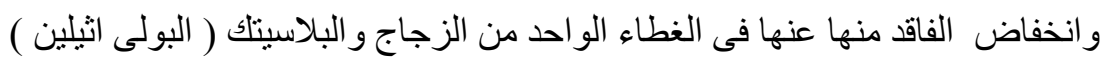

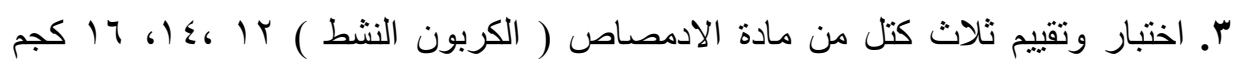

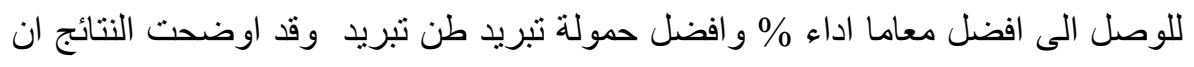

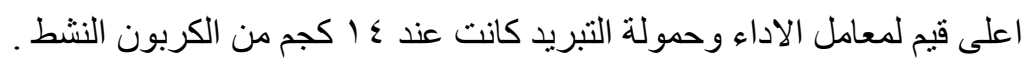

